\title{
Věřit znamená vidět. Biologie jako ideologie
}

\author{
Believing is Seeing. Biology as Ideology
}

\author{
Judith Lorber
}

\begin{abstract}
The text makes transparent the mechanisms used to legitimize gender differences via biology, as well as the epistemological fallacy of social and biological sciences with regard to current research on gender differences. Numerous examples make the case for hidden inequalities that are wrought into the very core of the structure and values of American society. The main argument illustrates the role of expectations in decoding our visual perception and reveals the ideology-laden biological accounts of reality.
\end{abstract}

KEY WORDS bathroom discrimination, biology, body, legitimization of gender differences, male and female socialization, menstruation and PMS, sickness and life expectancy.

Co by se přihodilo... kdyby znenadání, záhadně, mohli muži menstruovat a ženy nikoli?... Odpověd' je jasná - menstruace by se stala záviděníhodnou mužskou záležitostí, hodnou vychloubání.

Gloria Steinem (1978a: 110)

Freud tvrdil, že anatomie je osud, ale Aristoteles věřil, že osud člověka je určen jeho pozicí v sociálním řádu, a to nikoli pouze jako muže či ženy, ale jako člověka svobodného nebo otroka. Západní fillosofové a vědci až do 18. století věřili, že existuje pouze jedno pohlaví a ženské vnitřní genitále jsou pouze dovnitř obrácenými vnějšími genitáliemi mužskými (Dean-Jones 1991, Laqueur 1990a). Následně tedy viděli v děloze a vagině obrácený penis a šourek: „Č́m více renesanční anatomové pitvali, zkoumali a vizuálně zobrazovali ženské tělo, tím více a přesvědčivěji viděli ženské tělo jako verzi těla mužského“ (Laquer 1991a: 70). ${ }^{1}$

Současné západní myšlení vidí ženu a muže jako natolik tělesně odlišné, že se někdy zdají být dvěma různými biologickými druhy. Těla, po staletí důkladně mapovaná, se neproměnila. Proměna nastala v ospravedlněních genderové nerovnosti. Pokud se věřilo, že pozice všech lidí je určena Bohem, ženy a muži různých sociálních tříd měli své pozice přidělené. Jakmile však vědci začali božský základ sociálního řádu zpochybňovat a nahradili ho vírou v empirické vědění, najednou spatřili, že odlišnost žen od mužů spočívá v tom, že mají dělohy a menstruují. Takové anatomické rozdíly nutně ženy předurčovaly ke zcela odlišnému sociálnímu životu, než který vedli muži.

Ve skutečnosti však tělesný základ žen a mužů stejný je; s výjimkou pohlavních hormonů a rozmnožovacích orgánů mají ženy a muži těla podobná (Naftolin a Butz 1981). Již od polo- 
viny 19. století je navíc známo, že se mužské a ženské genitálie vyvíjí ze stejných plodových tkání, a tak se následkem různých genetických vad mohou rodit děti s genitáliemi oboupohlavními (Money a Ehrhardt 1972, Fausto-Sterling 1993). ${ }^{2}$ Pokud se dítě narodí s oboupohlavními genitáliemi, je připsání pohlaví značně libovolné. Suzanne Kessler (1990) vedla rozhovory se šesti lékařskými specialisty na pediatrickou intersexualitu a zjistila, že dítě s chromozomy $\mathrm{XY}$ a anomálními genitáliemi je kategorizováno jako chlapec či dívka $\mathrm{v}$ závislosti na velikosti penisu. Pokud je penis velmi malý, dítě je kategorizováno jako dívka a operativní přeměna pohlaví slouží k vytvoření umělé vaginy: „Ztotožnění pohlaví s genitáliemi se mohlo objevit pouze $\mathrm{v}$ době, kdy může lékařská věda vytvořit zdánlivě věrohodné a fungující genitálie, a důraz na dobrý falus, hodnocený nade vše, se mohl vynořit pouze v kultuře, která má rigidní estetická a funkční kritéria pro to, co zakládá mužnost... Objevuje se tu zarážející nedostatek pozornosti věnované požadavkům na velikost a tvar ženských genitálií, které se redukují na to, zda je vagina schopna přijmout penis“" $(20){ }^{3}$ Podle středověkého islámského práva bylo rozhodujícím kritériem pro určení pohlaví to, zda dítě močilo jako žena či jako muž, s tím, že byl zohledněn názor vyšetřující osoby (Sanders 1991: 77-78). ${ }^{4}$ Ke konci 19. století byla pro připsání pohlaví hermafroditům rozhodujícím kritériem př́tomnost či nepř́ítomnost vaječníků, protože žena neschopná reprodukce byla nedokonalá (Kessler 1990: 20).

Avšak v západních společnostech vidíme dvě oddělená pohlaví a dva rozlišitelné gendery, protože naše společnost spočívá na dvou třídách lidí, ženách a mužích. Při vyplňování téměř jakéhokoliv formuláře jsme tázáni, zda jsme mužského či ženského pohlaví, přestože fyziologicky i biologicky je to vzhledem $\mathrm{k}$ účelu formuláře zcela bezvýznamné. A každý, včetně transvestitů, transsexuálů a hermafroditů, poslušně vyplňuje jedno políčko. ${ }^{5}$ Nebot' všichni jsme genderově rozlišováni, proto zaškrtáváme. ${ }^{6}$ Každé dítě je kategorizováno jako „dívka“ či „,chlapec“, každý dospělý jako „žena“ či „muž“. Jakmile je jednou kategorie genderu připsána, jsou vlastnosti člověka genderově rozlišovány: Čímkoli je žena, musí být „ženské“, čímkoli je muž, musí být „mužské“. Analýza sociálních procesů, které vytvářejí kategorie nazývané „ženský a mužský“, „žena a muž“, ,homosexuál a heterosexuál“, odhaluje ideologické a mocenské rozdíly, zkostnatělé do těchto kategorií. V mnoha ohledech se těla fyziologicky liší, ale sociálními praktikami jsou zcela přetvořena tak, aby zapadala do hlavních kategorií společnosti, z nichž nejpronikavější je „mužská“ a „ženská“ a „muž“ a „žena“. V současné sociální konstrukci dvou pohlaví a dvou genderů je jeden konstruován jako nadřazený a druhý jako podřazený.

Pohlaví ani gender nejsou samozřejmými kategoriemi. Kombinace neslučitelných genů, genitálií a př́sun hormonů jsou při pohlavní kategorizaci opomíjeny, stejně jako kombinace neslučitelných identit, sexuality, vzhledu a chování jsou v sociální konstrukci genderových statusů ignorovány. Menstruace, laktace a těhotenství ženy od mužů neodlišují. Pouze některé ženy jsou těhotné, a to pouze po nějakou dobu; některé ženy nemají dělohu nebo vaječníky. Některé ženy dočasně přestaly menstruovat, jiné dospěly do menopauzy, některé podstoupily hysterektomii (operativní odnětí dělohy - pozn. překl.). Některé ženy po jistý čas kojí, někteří muži mají laktaci. Menstruace, laktace a těhotenství jsou individuální zkušenosti ženství (Levesque-Lopman 1988), nikoli determinanty sociálních kategorií „ženský“ nebo „žena“. Obdobně „,šichni muži nevytvářejí sperma a ve skutečnosti všechna spermata nejsou vytvořena muži. Transsexuál před chirurgickou změnou muže v ženu může být potenciálně (nebo i ve skutečnosti) schopný vytváření spermatu“ (Kessler a McKenna [1978] 1985: 2). 
Biologické a sociální vědy se spoléhají pouze na dvě kategorie pohlaví a genderu, což je epistemologicky sporné. Většina výzkumných postupů nezkoumá, zda jsou tělesné dovednosti a schopnosti ve skutečnosti mužům a ženám více méně společné (C. F. Epstein 1988). Začínají se dvěma sociálními kategoriemi (,ženy“, „muži“ ) a předpokládají, že jsou biologicky rozdílné (,ženské“, „mužské“). Hledají podobnosti uvnitř těchto kategorií a rozdíly mezi nimi a zjištění o těchto sociálních kategoriích následně připisují rozdílnosti pohlaví (Gelman, Collman a Maccoby 1986). Tento postup zrrídkakdy zpochybňuje kategorizaci jejich subjektů do dvou, a pouze dvou, skupin, přestože se často objevují významnější rozdílnosti uvnitř jedné skupiny než rozdílnosti mezi skupinami (Hyde 1990). Dále předpokládají, že rozdílnosti vyskytující se v raném dětství musí jít na vrub dědičnosti a nikoli sociálního učení, v rozporu s hojnými důkazy svědčícími o tom, že pokud je pohlaví jednou připsáno, zachází se s chlapci a dívkami různě a stejně různě na dívky a chlapce reagujeme.

Vezměme např́iklad jev chlapeckého vychloubačného chování a dívčí fyzické nešikovnosti v západních společnostech. Pokud chlapci hlučně pobíhají, řekneme, ,kluci jsou kluci“, což znamená, že nositelem fyzické agresivity musí být chromozom Y, protože právě ten se tak záhy a obvykle projevuje u chlapců. Ale projevují se chlapci opravdu všude na světě, v každé sociální skupině, hlučností a aktivností? Nebo se to děje pouze tam, kde jsou podporováni ve volném užívání těla, pohybu v prostoru, riskování, v zabývání se různými hrami a venkovními sporty? A naopak, co obyčejně rozumíme pod výrazem ,hází jako holka“? Zpravidla máme na mysli, že hází jako děvčátko, nositelka chromozomu XX. Konec konců, má jenom čtyři nebo pět let, tak jak by se mohla naučit takové neobratnosti? Ve skutečnosti hází děvče jako někdo, komu již bylo vštípeno omezování pohybu, ochrana vlastního těla a jeho femininní užívání:

Nejenom, že existuje typický styl házení jako holka, ale existuje i více či méně typický styl běhaní jako holka, lezení jako holka, plavání jako holka, trefování se jako holka. Společné mají předně to, že se celé tělo nedá do plynulého a cíleného pohybu, ale spíše že... pohyb je soustředěn do jedné části těla; a... má sklon nedosahovat, nerozpínat se, nepodporovat a nesledovat směr svého záměru.

(Young 1990: 146)

Dívka, která zakouší již v raném věku své tělo takto omezeným způsobem, je výtvorem své kultury a doby. Dívky a chlapci, kterým je ve třech letech dána do ruky tenisová raketa, a jsou vedeni k tomu být šampióny, používají svá těla podobným způsobem. Po pubertě budou mít chlapci širší ramena, větší sílu v pažích a budou se vyznačovat soustředěnými výbuchy energie; dívky budou mít více vytrvalosti, pružnosti a sílu v dolní části těla. Trénink, sport a fyzické cvičení podporuje, vyrovnává a potlačuje tyto rozdíly fyzických schopností, stejně jako individuální rozdíly svalstva a atletických schopností.

Sociobiologové tvrdí, že neúprosná práce genů vytváří zjevně odlišné mužské a ženské chování (Wilson 1975, 1978). Sociobiologické a biosociální výzkumné postupy a interpretace dat byly značně kritizovány za nedostatečný důkaz toho, že pouze a jedině rozdíly v biologickém pohlaví vytvářejí genderové chování. ${ }^{7}$ Stručně řečeno, ,jakékoli hodnocení dědičnosti rozdílů v chování podle pohlaví je omezeno... problémem vzájemného působení: muži a ženy bezprostředně vstupují do odlišných prostředí jen na základě svého anatomického pohlaví“ (McClintock 1979: 705). Důkazy vzájemného působení mezi hormonálními výstupy a sociální situací naznačují, že samotná situace ovlivňuje hladinu hormonů ve stejné 
míře jako hladina hormonů ovlivňuje chování. ${ }^{8}$ Fyzická těla jsou vždy těly sociálními: „Tělo, které nikdy nepřestane být tělem, je dáno $\mathrm{k}$ dispozici a přetvořeno sociálními praktikami““ (Connell 1987: 83).

Strukturování podle genderu nastává již před narozením, kdy amniocentéza (odebrání vzorku plodové vody pro zjištění prrípadných genetických vad - pozn. překl.) odhalí pohlaví dítěte; dítě dostane dívčí nebo chlapecké jméno. Pokud se jedná o ,špatné pohlavi““, nechtěné pohlaví, může být dítě potraceno. Jakmile je genderová kategorie připsána, tlak na shodu pohlaví a genderu je natolik silný, že k ustavení anatomie, která je v souladu s „nevhodnou“ genderovou identitou a genderovým chováním, se přistupuje k operativní změně pohlaví. Jak uvádí Margit Eichler: „Zdá se, že důvody operativní změny pohlaví jsou založeny na následující kruhové logice. Pohlaví určuje charakter. To je přirozené. Proto jsou neprrirozené př́pady, kdy biologické pohlaví nemá za následek očekávanou pohlavní identitu. Následně tedy musíme změnit biologické pohlaví (tj. př́rodu), abychom byli schopni udržet princip, podle kterého biologické pohlaví určuje charakter člověka“" (1989: 289).

\section{Co názorně dokládají sporty}

Sporty ukazují, jakými způsoby je tělo genderově ustavováno skrze sociální praktiky a jak je ženské tělo konstruováno jako podřadné. Začněme s tím, jak jsou závody př́isně děleny na ženské a mužské. Pokud je napadeno genderové zařazení, k určení kategorie, ve které má atlet/ka závodit, slouží chromozomy. Avšak anomálie, natolik častá, že se s ní setkáváme hned u několika žen na každém z větších sportovních závodů, prokazuje existenci chromozomu XY, který však kvůli genetické vadě nevytvořil mužskou anatomii a fyziologii. Protože jsou tyto ženy ženami v každém důležitém ohledu, prestižní Mezinárodní atletická federace naléhá, aby pohlaví bylo určováno prostou prohlídkou genitálií (Kolata 1992a). Transsexuálové by tímto testem prošli, ale Renée Richard, transsexuál, musel vyvolat soudní spor, aby po operativní přeměně z muže na ženu mohla hrát na tenisových turnajích jako žena. Nakonec turnaje hrála, přestože měla mužské chromozomy (Richard 1983). Kupodivu žádný z podkladů pro genderovou kategorizaci - chromozomy nebo genitálie - nemá žádnou souvislost s výkonem (Birrell a Cole 1990).

Na olympiádě se žena v př́ípadech chromozomové nejasnosti musí podrobit „sadě gynekologických a fyziologických prohlídek, aby se zjistilo, zda je dostatečně ženou na to, aby mohla závodit. Muži testováni nejsou“ (Carlson 1991: 26). Smyslem není přesné kategorizování žen a mužů, ale zajištění toho, aby muži nezávodili v ženských závodech. Obecně se usuzuje, že by v nich muži měli výhodu vzrůstu a síly. Tato praktika je považována za spravedlivou, protože se předpokládá, že všichni muži mají podobný vzrůst a sílu, odlišnou od všech žen. Avšak v olympijském boxu a zápasení spolu muži soupeří podle váhových kategorií. Některé ženy by mohly v mnoha sportech stejně úspěšně soutěžit s muži. Např́klad maraton běhají ženy pouze posledních zhruba dvacet let. Za tuto dobu svého působení v maratonském závodění zkrátily ženy čas doběhu o více než hodinu a půl; očekává se, že od roku 1998 budou běhat závody stejně rychle jako muži a možná v nejbližších padesáti letech doženou časy běhané muži také $\mathrm{v}$ závodech jiných délek, protože zvyšují svoji rychlost běhu rychleji než muži (Fausto-Sterling 1985: 213-218). ${ }^{9}$ 
Jakmile jsou ženy a muži kategorizováni odděleně, ovlivňují předpoklady o jejich fyziologii a atletických schopnostech pravidla závodění; následné sportovní výkony zpětně potvrzují způsoby, jakými je s ženami a muži při závodech zacházeno. Gymnastické náčiní je uzpůsobeno štíhlým, šlachovitým, prepubertálním dívkám a nikoli dospělým ženám; naopak mužské gymnastické náčiní je vyráběné na míru svalovitým, dospělým mužům a nikoli štíhlým prepubertálním chlapcům. Chlapci by mohli soupeřit s dívkami, ale není jim to dovoleno, gymnastky jsou pak z mužských závodů vyloučeny zcela (New York Times 1989b). Gymnastky jsou pouze děcč́tky, která budou diskvalifikována, jakmile dorostou (Vecsey 1990). Gymnasti mají status mužů. V ženské košíkové velikost míče a pravidla zacházení s ním posouvají styl hry do „pomalejší, méně napínavé a méně vzrušující podoby ,̌rádné‘ nebo ,mužskéc hry“ (Watson 1987: 441). Ženy nemají možnost hrát na veřejných závodech podle mužských pravidel. Při zimních olympijských hrách v roce 1992 museli ve svém povinném programu krasobruslaři skočit tři trojité skoky; krasobruslařky měly zakázáno skočit více než jeden. Tato pravidla poškodila umělecké krasobruslaře a atletické krasobruslařky (Janofsky 1992). Většina západních sportů je založena na fyzicky trénovaných mužských tělech: „Základem sportů se zdá být rychlost, vzrưst a síla. V takto pojatých sportech jsou ženy prrirozeně podřadné. Ale pokud by ženy byly historicky dominantním pohlavím, dozajista by se naše pojetí sportu vyvíjelo jinak. Nedělnímu odpolednímu vysílání by tak možná vévodily zápasy zdưrazňující pružnost, rovnováhu, sílu, načasování a malý vzrůst, honorované statisíci“ (English 1982: 266).

Organizované sporty jsou významným průmyslem, proto se to, kdo a na jaké úrovni soutěží, stává otázkou přerozdělování moci nebo rovnosti př́iležitostí. Celkový status atletek a atletů je spíše záležitostí ekonomickou, politickou a ideologickou, která toho má méně společného $\mathrm{s}$ individuálními fyziologickými schopnostmi, než s jejich kulturním a sociálním významem, a s tím, kdo tyto významy utváří a vydělává na nich. ${ }^{10}$ Přibližně dvacet let po schválení článku IX Zákona o občanských právech v USA, který zakazuje jakoukoli genderovou nerovnost ve školství, dotovaném federálními fondy, je cílem pro dalších pět let podpora univerzitního sportu a udělování stipendií v poměru 60 procent financí pro muže a 40 procent pro ženy (Morgan 1992).

Ospravedlnění rozdělování odměn (prestiže a financí) a př́ístupu k nim je problémem ideologickým, či dokonce morálním (Birrell 1988: 473-476, Hargreaves 1982). Jeden z těchto problémů představují masová média, která atlety oslavují a atletky opomíjejí. Michael Messner a jeho kolegové zjistili, že v USA v roce 1989 patřilo mužským sportům $92 \%$ televizního vysílání a sportům provozovaným ženami pouze $5 \%$, se zbývajícími $3 \%$ smíšeného a genderově neutrálního vysílání (Messner, Duncan a Jensen 1993). V roce 1990 ve čtyřech nejprodávanějších novinách v USA články o mužských sportech početně převážily články o ženských sportech poměrem 23:1. Messner a jeho kolegové dále objevili zjevnou hierarchii v uvádění jména. Atletky byly nejčastěji označovány křestním jménem, následované atlety černé pleti; a pouze bílí atleti byli běžně označováni př́ímením. Obdobně jsou ženské sportovní univerzitní oddíly pojmenovávány a označovány jmény, které je symbolicky feminizují a trivializují - mužské týmy jsou nazývány Tygry; ženské Kot’aty (Eitzen a Baca Zinn 1989). ${ }^{11}$

Předpoklady o tělech a jejich schopnostech jsou obratně utvářeny tak, aby se nerovný př́stup a rozdělování výhod staly přijatelnými (Hudson 1978; Messner 1988). Mediální zobrazování atletů oslavuje jejich sílu a moc, dokonce i jejich násilí (Hargreaves 1986). Mediální 
zobrazování atletek naopak tíhne ke zobrazování jejich ženské krásy a půvabu (takže nejsou skutečnými atletkami) nebo se zaměřuje na jejich vyhublá, malá, šlachovitá těla (čímž nejsou skutečnými ženami). Ve zpravodajství z ženských olympijských sportů

je láskyplná a zevrubná pozornost věnována gymnastkám skřítkovitého vzhledu; zvláštní a rozšǐřené zpravodajství je věnováno půvabným a oslnivým krasobruslařkám; pečlivá kamera zachycuje plynulé pohyby plavců a skokanů do vody. A následně, v oslnivém záblesku roztříšsěných obrazů zahlédnou diváci několik minut volejbalu, košíkové a rychlobruslení, běžeckého a sjezdového lyžování, s tím, jak televize přitaká pouhé existenci těchto událostí.

(Boutilier a San Giovanni 1983: 190) $)^{12}$

Mimořádné výkony atletek představovaných jako dospělé osoby by mohly diváky a organizátory sportovních událostí vést $\mathrm{k}$ zamyšlení nad vlastními stereotypy ženských aktérek jako skřítků, mořských panen a ledových královen, takové záběry však nejsou vysílány. Sporty tedy konstruují mužská těla jako plná síly, ženská potom jako sexuální: „Význam mužnosti $\mathrm{v}$ tělesném smyslu se týká především nadřazenosti mužů nad ženami a velebení jejich hegemonické mužnosti nad jinými skupinami lidí, což je základem jejich vlády nad ženami“ (Connell 1987: 85).

Pro chlapce a muže jako hráče a diváky se soutěživé sporty staly způsoby utváření maskulinní identity, ospravedlněným vybitím násilí a agrese a cestou vertikální mobility. ${ }^{13}$ Pro muže v západních společnostech je fyzická zdatnost důležitým ukazatelem mužnosti. ${ }^{14}$ Jak uvádí Erving Goffman (1963a): „V Americe existuje jen jeden typ muže, který za žádných okolností nepřijde do rozpaků: mladý, ženatý, bílý, heterosexuální, univerzitně vzdělaný protestantský otec pocházející ze severu, bydlící ve městě, zaměstnaný na plný úvazek, dobré pleti, přiměřené váhy a výšky, podávající skvělé sportovní výkony“ (128).

Propojení sportů s mužností, které je ve Spojených státech dané, vede atletky k nutnosti vypořádat se s veskrze rozporuplným statusem. Jedna studie univerzitních hráček košíkové (Watson 1987) zjistila, že košíkářky na palubovce „,se chovaly jako atleti“ - „poštuchovaly se, strkaly, faulovaly, vzájemně se dobíraly a vytvářely rychlé protiútoky, bránily, uživaly sprostá slovy a potily se“ (441); mimo palubovku zase „předstíraly“ ženy, se šatnou jako vyčkávacím prostorem: „zatímco jim př́prava na hru obyčejně zabrala čtvrthodinu, po hře jim nejméně čtvrthodinu zabralo sprchování a zbavení se potu atleta a další pưlhodinu jim trvalo oblékání, líčení se a úprava vlasů. Nezáleželo na tom, zda na dlouhou cestu domů nasedly na veřejnou dopravu nebo do auta. Průměrná doba oblékání a rituálů se neměnila“" (443).

Dalším ze způsobů, jak se vyrovnat se statusovými dilematy, je označení činností nebo jejich výsledků jako femininní nebo ženské (Mangan a Park 1987). V důsledku toho tedy kulturistky prohlašují, že „pružné tělo je sexy tělo“ (Surf a Hong 1984: 378). Je ironií, že toto pozlátko sexuality kulturistek téměř stálo jednu důstojnici velení, když se v armádních novinách objevily fotografie jejího „pózování v bikinách“ (Barkalow a Raab 1990: 203-209).

Toto odlišné znázorňování ženské tělesnosti ještě více podtrhuje ideologický podtext sportů, kdy je fyzická síla mužů neodvolatelným právem a ospravedlňuje mužskou tělesnou a sexuální nadvládu nad ženami. ${ }^{15}$ Pokud ženy prokáží fyzickou sílu, jsou označeny za nefemininní: „Být fyzicky silnou a ovládat se ohrožuje povolnost, snižuje možnost znásilnění a ženskost. Schopnost ubránit se znásilnění, nesdělovat svým tělem šanci na znásilnění, mít 
nadvládu nad užíváním svého těla a jeho významů mohou proměnit představu toho, co znamená být ženou“ (MacKinnon 1987: 122). Odpor proti této proměně byl v Americe po téměr̆ celé 20 . století ironicky zjevný u odbornic na tělesnou výchovu. Minimalizovaly tělesná cvičení a kladly velký důraz na ženský vzhled a způsoby a mužům přenechávaly soutěžení v organizovaných sportech (Birrell 1988: 461-62, Mangan a Park 1987).

\section{Ženy jsou stále častěji nemocné, muži umírají čím dál dříve}

Sociální praktiky neproměňují jenom těla atletů, ale nás všech a vkládají do nich kulturní a sociální významy. ${ }^{16}$ Fyzická síla a vytrvalost afro-amerických žen byla v 19. století vykořist'ována, zatímco u jižanských amerických paniček bílé pleti před válkou Jihu proti Severu naprosto přehlížena. Otrokyně pracovaly na poli bok po boku otroků, oraly a sklízely úrodu; otrokyně i jejich majitelky vykonávaly domácí těžké, fyzicky náročné práce. ${ }^{17}$ Představa ženy křehké a tělesně i duševně neschopné však zůstala zcela neotřesena i přes prokázané schopnosti žen (Jordanova 1989). Jak prohlásila Sojourner Truth na zasedání Spolku pro práva žen v Akronu, Ohio, v roce 1852, „Podívejte se na mě! Na mé ruce! [...] Orala jsem, sázela a svážela do stodol a žádný muž se mi nemohl postavit - a nejsem přesto ženou?““(1981: 160). Její slavné prohlášení výstižně ukazuje způsob, jakým byly ženy v 19. století oslabovány pojetím ženskosti - tělesně schopné dělnice a otrokyně byly považovány za podřadné ženy; tělesně křehké ženy vyšších a středních vrstev, plnohodnotné ženy, pak byly ekonomicky závislou třídou. ${ }^{18}$

V současných západních společnostech silně ovlivňují zdravotnické systémy a gender, spolu s rasou a sociální třídou zdraví a dlouhověkost nikoli skrze tělesné faktory, ale skrze rozdílné druhy prací, míru odpovědnosti za rodinu, míru rizika, zacházení se zdravím a nemocemi, rodinný stav a ekonomický status. ${ }^{19}$ Ženy jsou stále častěji nemocné a častěji navštěvují lékaře kvůli stresům z rutinní práce, péče o děti, opatrování zestárlých rodičů a „dvojí pracovní směně“ v zaměstnání a domácnosti. Muži jsou náchylnější k chronickým nemocem a nemocem bezprostředně ohrožujícím život, jako například infarkt, ale pokud jsou ženatí, jsou na tom duševně i fyzicky lépe než vdané ženy. Ve Spojených státech je nerovný přístup k předporodní péči důležitým faktorem vysoké četnosti dětí narozených s nízkou porodní váhou u Afro-Američanek a příčinou častých celoživotních traumat, vyvolaných vysokou četností předčasného úmrtí, u Afro-Američanů. ${ }^{20}$

Donedávna vyplácely pojišt'ovací společnosti vyšší důchody mužům než ženám s odůvodněním, že ženy žijí déle než muži (Harrison, Chin a Ficarrotto 1992). Nerozlišovaly podle rasy nebo etnika, přestože Američané evropského původu přežívají barevné ve Spojených státech přibližně o deset let. Naděje na dožití u Američanek s evropskými předky je o 15 let vyšší než u Afro-Američanů; rasové rozdíly v naději na dožití podle pohlaví jsou okolo osmi let. Následně tedy budou Američanky s evropskými předky pocházejícími ze střední tř́dy nejpravděpodobněji potřebovat ve stáří odbornou péči, protože své manžele přežívají (Ory a Warner 1990). Naopak Afro-Američané nejspíše utrpí úraz nebo zemřou mladí následkem vraždy, sebevraždy nebo při dopravní nehodě.

Při výzkumu genderových rozdílů v nemocnosti a úmrtnosti je nesmírně obtížné bezpečně vymezit vliv biologického pohlaví, jako ostatně i v jiných oblastech, ve kterých jsou biologické a sociální okolnosti navzájem propojené. Podle Loise Verbrugga, který se touto 
problematikou po mnoho let zabýval, „není známo, jakou náchylností a odolností jsou obyčejně muži a ženy vybaveni při početí ani jak proměňují stárnutí a sociální vlivy jejich vzrůst a povahu. Nejdůležitější potřebou populačních studií v rozdílech ve zdraví a úmrtnosti podle pohlaví je operacionalizace tohoto biologického základu“ (1989a: 296). Opravdovým problémem je skutečnost, že čistě biologický substrát není možné izolovat, protože lidská fyziognomie je sociálně konstruována a genderově rozlišena.

\section{„Kdyby muži mohli menstruovat“}

Přes důkazy tělesné zdatnosti jsou všechny ženy ve Spojených státech považovány za nezpůsobilé vykonávat jisté práce a tělesné činnosti jen na základě jejich pohlavních orgánů. Z lékařského hlediska ženy údajně činí období před menstruací, menstruace, těhotenství, rození dětí a menopauza nezpůsobilými bud' tělesně, anebo duševně. ${ }^{21}$ Antikoncepce může mít vedlejší účinky, potrat může vyústit do morálního stigmatu tím, že z žen, které vzaly odpovědnost za svoji tělesnou situaci do svých rukou, vytváŕí „dvojnásobné deviantky“ - mají tělesný problém a je jim za něj kladena vina (Lorber 1967). Podobně ženy, které si dobrovolně zvolí bezdětnost, jsou kritizovány za to, že nejsou úplnými ženami, a nedobrovolně neplodné ženy, at' již kvůli jejich vlastnímu nebo manželově problému s plodností, jsou stigmatizovány kvưli tomu, že nemají děti. ${ }^{22}$

To, co tedy ženy údajně dělá „skutečnými“ ženami - jejich tělesnost -, z nich zároveň činí občany druhé kategorie. Jen plodnost je používána jako měřítko toho, zda mohou či nemohou pracovat, přestože studie prokázaly stejnou míru pravděpodobnosti poškození produkce spermatu vlivem chemických látek a jiných rizik spojených s výkonem povolání. ${ }^{23}$ Plodnost žen tedy ideologicky ospravedlňuje jejich okrajový status jakožto pracovnic. Zastřena $\mathrm{v}$ této debatě zůstává obeznámenost žen s riziky jejich práce a dokonce možnost užívat tohoto vědění k omezení počtu svých potomků. Zdá se, že anglické hrnčiŕky, které na počátku 20. století, v době nelegálnosti potratů, používaly při své práci olovo, využívaly jeho nebezpečné účinky ke svým účelům: „Místní lékař zjistil v jednom vzorku sedmdesáti sedmi hrnčířek, které použivaly olovo, 21 mrtvě narozených nemluvňat narozených 8 ženám; 35 hrnčířek doznalo celkově 90 potratů. Přes značné nebezpečí používaly hrnčířky olovo k vyvolání potratů. Zjevně platilo za otřepanou pravdu, že vzít si hrnčířku je zárukou manželství, ve kterém bude možné počet dětí snadno regulovat" (Grieco a Whipp 1986: 135-36). V konečném rozhodnutí Federální vrchní soud v roce 1991 stanovil, že zaměstnavatelé nemohou používat ochranu plodu jako důvod pro odmítnutí povolení vykonávat nebezpečnou práci plodné ženě (Greenhouse 1991). Zaměstnavatelé mohou nechat rozhodnutí, zda omezit vystavování se riziku spojenému s výkonem povolání, nebo se vybavit ochrannými pracovními pomůckami, na samotných pracovnících (včetně mužů riskujících deformování spermatu) (Kilborn 1991).

Jiným př́kladem diskriminace žen na základě jejich tělesnosti je užití menstruace ke zpochybnění jejich duševních a tělesných schopností. Jelikož jsou menstruující ženy podřizenou skupinou, bývá menstruace používána jako všeprostupující ospravedlnění jejich podřízeného postavení (Delaney, Lupton a Toth 1977). Představy o znečištění byly v Evropě a Americe nahrazeny vědeckými studiemi o špatném vlivu vy̌̌šího vzdělání na schopnost žen menstruovat (Bullough a Voght 1973, Vertinsky 1990: 39-68). ${ }^{24} \mathrm{Na}$ konci 70. let 20. století, s postupným pro- 
nikáním žen do atletických závodů, podobné vědecké studie zjistily, že ženy v důsledku tvrdého tréninku nutně přestanou menstruovat, protože budou mít nedostatek tělesného tuku na probíhající ovulaci (Brozan 1978). Avšak když tým výzkumníků prováděl jednoletou komparativní studii u 66 žen, z nichž se 21 připravovalo na maraton, 22 běhalo týdně více než hodinu a 23 cvičilo méně než hodinu aerobiku týdně - zjistili, že pouze 20 procent žen v jakékoli skupině mělo „normální“ menstruační cyklus každý měsíc (Prior a kol. 1990). Nebezpečí intenzivního tréninku pro ženskou plodnost bylo přeháněno $\mathrm{v}$ kontextu pronikání žen do jim dřive uzavřených arén.

Předmenstruační napětí je jedním z dalších údajně biologických jevů, které podkopávají sociální status žen (Rittenhouse 1991). Před šedesáti lety bylo předmenstruační napětí popsáno a připsáno hormonálním př́činám; od té doby většina vědcủ tento biologický model následovala - definovala ho jako syndrom s př́ćinou, jako patologii, která se odehrává v jedinci. Kritici poznamenávají, že existují nejasnosti ohledně toho, co to je, kdy to nastává, zda-li je to jeden syndrom a jaké jsou jeho následky. ${ }^{25}$ Nechvalně známé spojení mezi předmenstruačním napětím a trestnými činy, sebevraždami a dalším destruktivním jednáním mohou být výsledkem emocionálního stresu, který způsobuje jak změny menstruačního cyklu, tak i patologické chování; avšak ženy, podstupující důležité zkoušky, mají stejnou pravděpodobnost být před menstruací stejně jako ženy, které páchají trestné činy (Parlee 1982a).

Některé ženy zažívají předmenstruační tělesné změny, jiné zaznamenávají výkyvy nálad, nebo mírnějši či těžší formy kombinace obou: „Nejčastějšími emocionálními stavy, udávanými ve studiích PMS, jsou napětí, úzkost, deprese, podrážděnost a nepřátelskost. Somatické potíže zahrnují nadýmání v podbřišku, otoky, citlivost prsů, bolesti hlavy a zad. Často uváděnými změnami v chování jsou vyhýbání se sociálním kontaktům, změny pracovních návyků, zvýšený sklon k hádavosti (zvláště s manželem/partnerem a dětmi) a období plačtivosti““ (Abplanalp 1983: 109). Mnoho žen zažíá mírné symptomy (stejně jako mnoho žen pocituje mírnou nepohodu během menstruace); četnost výrazných syndromů (nebo zcela ochromující období menstruace) je méně častá.

Mnoho žen a mužů zaživá proměny nálad během různých dnů $\mathrm{v}$ týdnu; $\mathrm{u}$ žen mohou tyto proměny pozměnit nebo zesílit předmenstruační cykly výkyvů nálad (Hoffmann 1982, Rossi a Rossi 1977). Mary Brown Parlee (1982b) zjistila, že jednotlivé ženy připisují tyto proměny nálad spíše jiným příčinám než menstruačnímu cyklu, vnímají je např́iklad jako reakci na problémy v práci či doma; když však byla data seskupena, vliv menstruačního cyklu byl zvýrazněn, protože ostatní pravidelnosti byly charakteristické pouze pro danou osobu. Každodenní výčet činností vytvořil „obraz toho, co bychom mohli nazvat: ,předmenstruačním euforickým syndromem“, což je opakem negativního ztělesnění předmenstruačního napětí“ (Parlee 1982b: 130). Zpětné převyprávění od stejných žen však jejich pocity zachycovalo ve stereotypních pojmech.

Jedna lékařka sarkasticky poznamenala, že vliv toho, co je definováno jako předmenstruační syndrom - zlostnost a podrážděnost - vyniká pouze proto, že takové chování je opakem tř́ týdnů př́jemné společenskosti (Guinan 1988). Emily Martin (1987) podotýká, že z feministické perspektivy může být předmenstruační syndrom př́znivý - nikoli pouze jako projev běžně potlačovaného hněvu, vzniklého každodenním ponižováním, kterému jsou ženy podrobovány, ale jako odlišný druh vědomí, soustředění a tvořivosti: „Znamená ztráta schopnosti soustředění větší schopnost střetávání? Svalová ochablost zisk schopnosti odpočinout si? Snížená výkonnost větší pozornost menšímu počtu úkolů?““ (128). 
Obdobně je i menopauza definována jako nemoc a její sociální př́činy jsou vyloučeny. ${ }^{26}$ Západní kultura vnucuje menstruaci, menopauze, těhotenství a porodu negativní konotaci vzdálenosti, pocit, že tělo a duše jsou odděleny. ${ }^{27}$ Západním ženám není poskytnuta žádná príležitost přemýšlet o svých tělech jako o tělech umístěných v čase a prostoru stejným způsobem, jakým muži v naší kultuře zažívají erekci a orgasmy - jako o rozpínavosti jich samých. Na rozdíl od západních společností, kde tělesnost a sociální status bývají často rozpojovány (Rossi 1980), původní obyvatelé Ameriky a další kultury propojují věkové cykly žen a mužů se společenstvím. Pro ženy se menstruace a porodní rituály stávají začleňujícími a oslavnými rituály přechodu (Buckley a Gottleib 1988, Powers 1980). Peruánské ženy dosahují plné dospělosti v době okolo menopauzy, získávají sociální a finanční výhody a osvobození od každodenních prací a od rozvětvených rodin (Barnett 1988). ${ }^{28}$

To, co by zůstávalo mimo pozornost žen jako opakovaná, snesitelná událost, se stává syndromem, patologií, „nemoci“", pokud je to lékařskými odborníky takto označeno (Dodd 1989, Fisher 1986). Přestože zajisté existují ženy, kterým by lékařská péče pomohla od oslabujících předmenstruačních, menstruačních a menopauzálních stavů, zdaleka nepředstavují většinu (Yankauskas 1990). Nicméně o všech ženách se tvrdí, že trpí (a následně také celé jejich okolí) „hrůzami“ toho „období v měsíci“ nebo toho „„̌ivotního obdobi““. V naší společnosti tyto syndromy ponižují ženy jako skupinu a ospravedlňují jejich podřadný sociální status jakožto neplnohodnotných lidských bytostí. ${ }^{29}$ Protože během svého života všechny dospělé ženy zažívají některý z těchto tělesných stavů, následně tím, že jsou definovány svou tělesností, jsou všechny ženy téměř pořád „nemocné“.

\section{Špinavé tajnưstky}

$\mathrm{K}$ ospravedlňování rozdílů v sociálním statusu bývají ve větší či menší míře uváděny rozdíly pohlaví (Epstein 1988). Údajná větší síla mužů racionalizuje dělbu práce na základě genderu, i když skutečně těžkou práci vykonávají stroje: „V mužské práci se snoubí dvě schopnosti: tělesný výkon a technická zdatnost. Muži tyto dvě vlastnosti propojují a přivlastňují si je jako mužské schopnosti. Každá z nich jim totiž propůjčuje jistou míru moci. Ne přsprúíliš velkou, jenom takové množství moci, které podepírá nárok na vyšší mzdy, na menší dohled při práci a více volnosti ze strany vedení (Cockburn 1985: 100). Tato „větší síla“ je také sociálně konstruována a je vestavěna do genderové stratifikace uplatňované v práci a ve společnosti obecně:

Malé biologické rozdíly se změní ve větší tělesné rozdíly, které jsou následně přeměněny na taktické výhody v sociální, politické a ideologické mocenské hře. Ženy se rodí menší než muži. Tento rozdíl je výchovou zveličován, takže ženy dorůstají do dospělosti méně fyzicky silné a schopné než by mohly být. Jsou vyloučeny $\mathrm{z}$ celé řady manuálních prací a $\mathrm{v}$ důsledku toho také $\mathrm{z}$ kontroly vykonávané nad technologiemi. Tento důsledek se promítá do každodenního života: v konečném důsledku se ženy staly závislými na mužích při výměně kola u auta, zasklení rozbitého okna nebo náhrady prasklé střešní břidlice. A co více, ženy jsou muži tělesně obtěžovány a znásilňovány: nejdříve jsou ženy relativně oslabeny; slabost je přetvořena ve zranitelnost; a zranitelnost otevírá cestu k zastrašování a využívání. Stěží můžeme přecenit rozsah a dlouhodobost takto vzniklého utlačování.

(Cockburn 1983: 204) 
Meta-analýza studií o genderových rozdílech $\mathrm{v}$ matematických schopnostech a prostorové představivosti zjistila, že muži mají výraznou výhodu ve schopnosti mentální rotace vyobrazení, mírnou výhodu ve vizuálním vnímání vodorovnosti a svislosti a v matematických výkonech, a malou výhodu ve schopnosti rozeznání postavy v poli (Hyde 1990). Bylo by možné tvrdit, že tyto výhody objasňují, proč se za tak krátkou dobu, během níž se počítače staly všudyprítomné v kancelářích, školách a domovech, stala práce na nich tak genderově rozlišenou: muži vyrábějí, programují a prodávají počítače, vedou s nimi války, dělají na nich vědu a tvoří umění; ženy propojují mikrosoučástky v továrnách na počítače a ukládají data v kancelářích vybavených počítači; chlapci hrají hry, sdružují se a páchají s počítači trestné činy; dívky zř́́dkakdy nalezneme v počítačových klubech, táborech nebo učebnách. ${ }^{30}$

Avšak ve 40 . letech 20 . století byly ženy najímány jako programátorky, protože „tato práce se zdála být podobná jednoduchým kancelářským úkolům. Ve skutečnosti však programování vyžadovalo celý souhrn dovedností abstraktní logiky, matematiky, elektrických obvodů a strojírenství, které všechny... ženy v této práci vykonávaly. Jakmile však bylo programování uznáno ,duševně náročnou“ činností, stalo se pro muže přitažlivé“" (Donato 1990: 170). Grace M. Hopper, matematička a průkopnice ve zpracování dat, proslula svým dílem o programovacím jazyku (Perry a Greber 1990: 86). Avšak v 60. letech bylo programování rozdrobeno do více či méně specializovaných oblastí a ženy měly $\mathrm{v} 70$. a 80 . letech v počítačovém odvětví přístup pouze ke špatně placeným specializacím. V každém období se zaměstnavatelé dovolávali údajných ženských a mužských přirozených schopností uzpůsobujících je k práci, na kterou byli najímáni (Donato 1990).

O každodenním genderově rozdílném chování, které je považováno za dané, se domníváme, že tyto rozdíly v činnostech žen a mužů pocházejí z biologie. Vezměme si obvykle nepovšimnutý príklad: pokud spolu v moderních společnostech žena a muž tvořící pár jedou autem, je daleko pravděpodobnější, že bude řídit muž, přestože žena může být za volantem schopnější. Molly Haskell (1989) tento jev nazývá „špinavými tajnůstkami manželství: syndrom chotě jako mizerného řidiče“ (26). Muži řídí auta, at’ již jsou či nejsou dobrými řidiči, protože muži a stroje jsou „přirozeným“ spojením (Scharff 1991). ${ }^{31}$ Nicméně někteří mladíci jezdí na důkaz své mužnosti bezohledně, a proto je pojištění auta pro muže mladší 25 let na většině území Spojených států obzvlášt' drahé. Propojení mezi schopností rídit a sociální mocí je nejjednoznačnější v Saúdské Arábii, kde je ženám zcela zakázáno auta řídit (LeMoyne 1990b).

$\mathrm{V}$ počátcích automobilismu prijaly feministky symboliku mobility jako emancipaci: „Nosily brýle a prachovky, třímaly rámy pneumatik a brašny s nářadím a když se zmocnily volantu, oznámily svůj úmysl překročit hranice ženského prostoru“ (Scharff 1991: 68). Rízení automobilů jim umožnilo zapojení do kampaně za ženské volební právo v oblastech, které ve Spojených státech nebyly obslouženy veřejnou dopravou, a účinné využití taktiky automobilových kolon a projevů přednášených z aut (67-68). Sandra Gilbert také poznamenává, že během 1. světové války se dovednost ř́́dit stala tělesně, duševně a dokonce smyslově osvobozující:

pro zdravotní sestry a řidičky záchranných vozů, doktorky a kurýrky byl průběh moderních bojů velmi odlišný od toho, co zažívali vojáci v zákopech. Když konečně dostaly šanci zasednout za volant, ubíraly se tyto post-viktoriánské dívky s větrem o závod po neznámých silnicích jako při dobrodružství objevování nových zemí, zatímco jejich bratři se stále hlouběji zakopávali do fran- 
couzského bahna... Odklízení zraněných a mrtvých z jejich strnulých poloh těmto kdysi uhlazeným dcerám konečně umožnilo ukázat svoji cenu a ony se míhaly po válečných pustinách s činorodou láskou Wagnerových Valkýr, samotná jejich pohyblivost přemíst’ovala nespočetné nepohyblivé hrdiny do bezpečného nebe.

(1983: 438-39)

\section{Společenská těla a problém toalety}

Lidé mají rozdílné genitálie, odlišné sekundární pohlavní znaky, různé způsoby podílení se na rozmnožování, rozmanité zážitky orgasmů a jiné pravidelnosti nemocnosti a stárnutí. Ale svá těla zažíváme různými způsoby všichni a tyto zkušenosti se proměňují s naším růstem, stárnutím, churavěním a umíráním. Těla těhotných a netěhotných žen, malých, vysokých, se všemi funkčními končetinami i těmi, pro něž je tělesný pohyb výzvou, všechna tato těla jsou rozdílná. Avšak stěžejní sociální kategorie seskupují tyto znaky způsobem, který tyransky převálcuje individuální zkušenosti. ${ }^{32}$

Genderové kategorie jsou rozpolcené jejich sociálními konstrukcemi tělesných znaků. Afro-Američané sdílejí privilegovaný status s Američany evropského původu vzhledem k ženám jejich vlastní sociální kategorie, ale Afro-Američané a Afro-Američanky jsou diskriminováni kvůli barvě své pleti (1984). Vysoká žena či malý muž mají podobné sociální zážitky na veřejnosti, ve společnosti, která upřednostňuje vysoké muže a malé ženy - oba jsou jistým způsobem stigmatizováni při navazování známostí i v manželství (Goffman 1963a). Tělesně postižení muži a ženy jsou ve Spojených státech vnímáni jako asexuální (Zola 1982a). Muž však může být obdivován za prokázání silné vůle v překonávání závislosti, přestože se spoléhá na podporu ženy; žena může zůstat sociálně závislá, ale paradoxně nemá nikoho, kdo by se o ni postaral (Fine a Asch 1985).

Tělesné rozdíly mezi mužskými a ženskými těly zcela jistě existují - přinejmenším toto by nám ozřejmila místnost plná nahých lidí -, ale rozdíly jsou sociálně nevýznamné, dokud nejsou sociálními praktikami proměněny $\mathrm{v}$ sociální fakta. Sociální proměna ženské a mužské tělesnosti do postavení nerovnosti je názorně doložitelná na problému toalet. Většina budov s genderově oddělenými toaletami jich má stejný počet pro ženy i muže. Pokud je v budově hodně lidí, čeká vždy dlouhá fronta před dámskými toaletami, ale zř́́dkakdy před pánskými. Moderní ženské oblečení a potřeba žen při močení sedět nebo dřepět prodlužuje dobu, kterou na toaletě stráví (aby mohly použít toaletu, musí si sundat kalhotky, podvazkový pás, punčocháče a kalhoty); pánské záchodky mají zpravidla kabinky a zároveň i pisoáry. Chlapečci chodí častěji na záchod s ženami než děvčátka s muži. Těhotné ženy musí často močit; muži neotěhotní, ale jejich problémy s prostatou je mohou posílat na toaletu stejně často jako těhotné ženy. Menstruujícím ženám to na toaletě trvá déle; muži nemenstruují, což ale platí i pro ženy po menopauze, avšak potřeba častěji močit narůstá s věkem, zejména u žen. Starším lidem močení také trvá déle a pravděpodobněji to budou postarší ženy než muži, protože ženy žijí déle. Kulturní, tělesné a demografické spojení oblečení, četnosti močení, menstruace, stáří a péče o děti přispívá k častějšímu používání dámských toalet. Přestože se stejný počet toalet jeví jako spravedlivý, skutečná spravedlnost by znamenala více dámských toalet nebo možnost používat po určitou dobu také pánské toalety 
(Moloch 1988). ${ }^{33}$ Také další genderová překážka je údajně diktovaná biologickými rozdíly mezi ženami a muži a vytváří symbolické sociální prostory, které zř́ídkakdy prolomíme, i když se objeví problém identity:

Protože veřejné ubytování stále více slouží mnohojazyčné klientele, byla označení „pánové“ a „dámy“ nahrazena znaky zobrazujícími postavu v „mužském“ oblečení - kalhotách - a postavu oděnou $\mathrm{v}$,ženském“ oblečení - sukni či šatech. Avšak nikdo (s výjimkou transvestitů a transsexuálů) neinterpretuje tyto symboly doslovně nebo mimeticky. Žena v kalhotách by za normálních okolností nevešla do dveří označených postavou v kalhotách, a stejně tak by kněz $\mathrm{v}$ sutaně nebo př́znivec hnutí Haré Kršna, oblečený do šatů, nezamířil do dveři označených sukní... Takto oblečení lidé upřednostňují nechápat tuto postavu doslovně: ti v kalhotách tam; ti v sukních tam.

(Gerber 1992: 13-14)

Můj př́tel a já jsme „osvobodili““ mnoho pánských toalet, ale jedna žena byla za takový čin zatčena (i když poté naštěstí propuštěna) (New York Times 1990).

Problém toalet je výsledkem způsobu, jakým jsou v západní kultuře genderově odlišná těla hodnocena různým způsobem: mužská sociální těla jsou měřítkem toho, co je „lidské“. Např́klad obsah osnov vojenské akademie ve West Pointu slouží k výcviku vojenských velitelů a fyzická zdatnost je používána jako důležité měřítko schopnosti vůdcovství (Yoder 1989). Když byly ženy přijaty jako kadetky, vyšlo najevo, že testy fyzické zdatnosti, jako např́ílad schopnost rychle zdolat 2,40 metrů vysokou zed', byly vytvořeny s ohledem na mužskou fyziognomii - přitáhnout se a přelézt pomocí síly horní části těla. Namísto sestavení testů fyzické zdatnosti pro ženy West Point poskytl pomocné zařízení, které používaly převážně ženy, ale i tak je to stálo při testování několik bodů (v prrípadě stěny byl poskytnut podstavec). Nakonec si ale ženy vytvořily způsob, jak svá těla úspěšně používat. Janice Yoder (1989) celou situaci popisuje následovně: „Pozorovala jsem jednoho dne tuto překážku, když k ní jedna žena přistoupila předepsaným způsobem, tj. pověsila se na ní za konečky prstů, avšak potom udělala neobvyklou věc: svýma volně visícíma nohama vystoupala po stěně, až se dostala do polohy, kdy byly její ruce i nohy na horní hraně stěny. Potom jednoduše přehodila zbytek svého těla přes stěnu a přelezla. Vyřešila tento problém tím, že využila jednu z ženských předností: sílu dolní části těla“ (530). Pokud tedy bude West Point měřit vůdcovské schopnosti podle fyzické síly, potom se ženské pánve mohou osvědčit stejně dobře jako mužská ramena.

Grayova Anatomie, použivaná po celé století, z čehož značnou část tvořilo století dvacáté, zobrazovala lidské tělo jako mužské. $Z$ ženského těla byly zobrazovány pouze ty části, které se lišily od mužských (Laquer 1990a, 166-167). ${ }^{34}$ Denise Riley uvádí, že pokud si ženská, mužská a lidská těla představíme jako „trojúhelník identifikací, potom se jen zř́́dkakdy jedná o rovnostranný trojúhelník, ve kterém jsou obě pohlaví zobrazována ve stejných vzdálenostech od vrcholku těla lidského“ (1988: 197). Catherine MacKinnon tvrdí, že v západní společnosti je univerzální lidskost mužská, protože

prakticky každá vlastnost, kterou se muži odlišují od žen, je v této společností přijímána kladně. Mužská fyziognomie určuje podobu většiny sportů, jejich potřeby určují pojištění vozidla a zdravotní pojištění, jejich sociálně stanovené biografie definují očekávání na pracovišti a jejich úspěšné vzorce kariéry, jejich vyhlídky a obavy definují kvalitu stipendií, jejich zkušenosti a posedlosti stanovují zásluhy, jejich objektivace života dávají podobu umění, jejich vojenská služba definuje občanství, 
jejich př́tomnost určuje status rodiny, jejich neschopnost vyjít se sebou navzájem - jejich války a vztahy - definuje historii, jejich vzhled definuje boha a jejich genitálie definují pohlaví. Nebot' všechno to, co je odlišuje od žen, to, co se rovná plánu afirmativní akce, je ve skutečnosti strukturou a hodnotami americké společnosti.

Přeložila Alice Navrátilová

\section{Poznámky}

$1 \quad \mathrm{O}$,estetice anatomických rozdílů“ nebo o tom, jak jsou anatomická zobrazení složitými konstrukcemi toho, co vidíme a toho, v co věříme, viz Laqueur 1990a, zejména 163-169.

Ze stejného důvodu je kůže z penisu a šourku používána $\mathrm{k}$ vytvoření vaginy a pysků u mužů postupujících operaci na změnu pohlaví.

3 Plastičtí chirurgové používají pro tyto operace termín „vyjasnění genitálií“. Bývá vhodnější operaci provést, když je dítě starší, ale rodiče velmi trpí, když neznají pohlaví svého dítěte (Richard C. Sadove M. D., osobní komunikace; Weiss [v tisku]).

4 Poměrně častým stavem u novorozených chlapců je nedostatečné uzavření uretranu a močení z jiné části než z vrcholu penisu.

5 Hermafrodité se rodí s chybějícími pohlavními chromozomy, které mají za následek odlišný pubertální vývoj, nebo mají při narození oboupohlavní genitálie - zvětšený klitoris, který se podobá penisu, nebo velmi malý penis, který se podobá klitorisu, nedostatečně otevřenou vaginu, která připomíná šourek, nebo nedostatečně uzavřený šourek, který připomíná vaginu atd. Viz Money a Ehrhart 1972.

$6 \quad$ Viz také Bourdieu [1980] 1990: 66-67.

Birke 1986; Fausto-Sterling 1985; Hubbard 1990; Hubbard, Henifin a Fried 1979; Longino a Doell 1983; Naftolin a Butz 1981; Sayers 1982.

$8 \quad$ Fausto-Sterling 1985; Kemper 1990; Treadwell 1987. Nedávné výzkumy prováděné na rybách cichlidkách ukázaly, že dominance vytváří mozkové buňky a hormonální změny a nikoli opačně a že testosteron podněcuje dominantní chování u samiček hyen (Angier 1991, 1992b).

Ve starém Řecku ženy závodily v běhu na své vlastní Olympiádě, jak to dokládá váza ve Vatikánu. Jejich atletické závody byly pořádány na počest Héry a předváděly se ženskému publiku (Pomeroy 1975, 137).

10 Birrell 1988: 479-91; Boutilier a SanGiovanni 1983; M. A. Hall 1988; Hargreaves 1986; Messner a Sabo 1990; Moran 1992; Slatton a Birrell 1984, Willis 1982.

11 První ženské družstvo košíkářek ve West Pointu se jmenovalo „Sladké plebejky“. Bylo změněno na „Armádní družstvo košíkářek“ trenérem (mužem), který původní název nepovažoval za dostatečně seriózní. Ženy si vybraly toto označení během svého prvního roku - „smacks“ je jedním z výrazů pro ,plebs“ (Barkalow 1990: 126).

12 Pro diskusi viz Boutilier a SanGiovanni 1983: 183-218; Theberge a Cronk 1986.

13 Dunning 1986; Kemper 1990: 167-206; Messner 1987, 1989, 1992.

14 Fine 1987; Glassner 1992; Majors 1990.

15 Hargreaves 1986; Messner 1988; Olson 1990; Theberge 1987; Willis 1982.

16 Gallagher a Laqueur 1987; Jordanova 1989; Jacobus, Keller a Shuttleworth 1990; Martin 1987.

17 Clinton 1982: 18-35; Fox-Genovese 1988: 166, 193; J. Jones 1986: 11-29; Matthei 1982: 87-89; White 1985: 120-121. 
Literatura

Abplanalp, J. M. 1983. „Premenstrual syndrome: A selective review.“ Women and Health, 8 (2-3): 107-123.

Angier, N. 1991. „In fish, social status goes right to the brain.“ New York Times, Science Section, 12. 11 . 
Angier, N. 1992. „Hyenas’ hormone flow puts females in charge.“ New York Times, Science Section, 7. 1.

Barkalow, C, Raab, A. 1990. In the Men's House. New York: Poseidon Press.

Barnett, E. A. 1988. „Le edad critica: The positive experience of menopause in a small Peruvian town." In P. Whelehan a kol. (eds.) Women and Health: Cross-cultural Perspectives. Granby, Mass.: Bergin \& Garvey.

Bertin, J. E. 1989. „Women's health and women's rights: Reproductive hazards in the workplace.“ In K. S. Ratcliff a kol. (eds.) Healing Technology: Feminist Perspectives. Ann Arbor: University of Michigan Press.

Bird, Ch. E., Freemont, A. M. 1991. „Gender, time, and health.“ Journal of Health and Social Behaviour, 32: 114-129.

Birke, L. 1986. Women, Feminism and Biology: The Feminist Challenge. New York: Methuen.

Birrell, S. J. 1988. „Discourses on gender/sport relationship. From women in sport to gender relations.“ In K. Pandolf (ed.) Excercise and Sport Science Reviews, vol. 16. New York: Macmillan.

Birrell, S. J., Cole, S. L. 1990. „Double fault: Renée Richards and the construction and naturalisation of difference." Sociology of Sport Journal, 7: 1-21.

Bourdieu, P. 1990 [1980]. The Logic of Practice. Stanford, Calif.: Stanford University Press.

Boutilier, M. A., SanGiovanni, L. 1983. The Sporting Woman. Champaign, Ill.: Human Kinetics.

Brown, J. K. 1982. „A note on the division of labor by sex.“ American Anthropologist, 72: 1074-1078.

Brozan, N. 1978. „Training linked to disruption of female reproductive cycle.“ New York Times, 17. 4.

Buckley, T., Gottleib, A. (eds.) 1988. Blood Magic: The Anthropology of Menstruation. Berkeley: University of California Press.

Bullough, V., Voght, M. 1973. „Women, menstruation and nineteenth-century medicine. Bulletin of the History of Medicine, 47: 66-82.

Calhoun, L. G., Selby, J. W. 1980. „Voluntary childlessness, involuntary childlessness, and having children: A study of social perceptions." Family Relations, 29: 181-183.

Carlson, A. 1991. „When is a woman not a woman?“ Women's Sport and Fitness, March: 24-29.

Clinton, C. 1982. The Plantation Mistress. NewYork: Pantheon.

Cockburn, C. 1983. Brothers: Male Dominance and Technological Change. London: Pluto Press.

Cockburn, C. 1985. Machinery of Dominance. Women, Menand Technological Know-how. London: Pluto Press.

Connell, R. W. 1987. Gender and Power: Society, the Person, and Sexual Politics. Stanford, Calif:: Stanford University Press.

Daly, M. 1978. Gyn/Ecology: The Methaethics of Radical Feminism. Boston: Beacon Press.

Davis, A. Y. 1983. Women, Race and Class. New York: Vintage.

Dean-Jones, L. 1991. „The cultural construct of the female body in classical Greek science.“ In S. B. Pomeroy (ed.) Women's History and Ancient History. Chapel Hill: University of North Carolina Press. 
Delaney, J., Lupton, M. J., Toth, E. 1977. The Curse: A Cultural History of Menstruation. New York: New American Library.

Dodd, A. D. 1989. Intimate Adversaries: Cultural Conflict between Doctors and Women Patients. Philadelphia: University of Pennsylvania Press.

Donato, K. M. 1990. „Programming for change? The growing demand for women systeme analysts.“ In B. F. Reskin and P. A. Roos (eds.) Job Queues, Gender Queues: Explaining Women's Inroads into Male Occupations. Philadelphia: Temple University Press.

Dunning, E. 1986. „Sport as a male preserve: Notes on the social sources of masculine identity and its transformations." Theory, Culture and Society, 3: 79-90.

Edwards, P. 1990. „The army and the microworld: Computers and the politics of gender identity.“ Signs, 16: 102-127.

Ehrenreich, B., English, D. 1973. Complaints and Disorders: The Sexual Politics of Sickness. Westbury, N. Y.: Feminist Press.

Eichler, M. 1989. „Sex change operations: The last bulwark of the double standard.“ In L. Richardson, V. Taylor (eds.) Feminist Frontiers II. New York: Random House.

Eisenstein, Z. 1988. The Female Body and the Law. Berkeley: University of California Press.

Eitzen, D. S., Baca Zinn, M. 1989. „,The de-athleticization of women: The naming and gender marking of collegiate sport teams.“ Sociology of Sport Journal, 6: 362-370.

English, J. 1982. „Sex equality in sports.“ In Femininity, Masculinity, and Androgyny, ed. by M. Vetterling-Braggin. Boston: Littlefield, Adams.

Epstein, C. F. 1988. Deceptive Distinctions: Sex, Gender and the Social Order. New Haven: Yale University Press.

Fausto-Sterling, A. 1985. Myths of Gender: Biological Theories about Women and Men. New York: Basic Books.

Fausto-Sterling, A. 1993. „How many sexes are there?“ New York Times, Op-ed Page, 12. 3.

Fernández-Kelly, M. P., García, A. M. 1988. „Invisible amids glitter: Hispanic women in the Southern California electronic industry." In A. Statham, E. M. Miller, H. O. Mauksch (eds.) The Worth of Women's Work. Albany: State University of New York Press.

Fine, G. A. 1987a. With the Boys: Little League Baseball and Preadolescent Culture. Chicago: University of Chicago Press.

Fine, G. A. 1987b. „One of the boys: Women in male-dominated settings.“ In M. S. Kimmel (ed.) Changing Men: New Directions in Research on Men and Masculinity. Newbury Park, Calif.: Sage.

Fine, M., Asch, A. 1985. „Disabled women: Sexism without the pedestal.“ In M. J. Deegan a N. A. Brooks (eds.) Women and Disability: The Double Handicap. New Brunshwick, N. J.: Transaction.

Fisher, S. 1986. In the Patient's Best Interest: Women and the Politics of Medical Decisions. New Brunshwick, N. J.: Rutgers University Press.

Fox-Genovese, E. 1988. Within the Plantation Household: Black and White Women of the Old South. Chapel Hill, N. C.: University of North Carolina Press.

Gallagher, C., Laqueur, T. (eds.) 1987. The Making of the Modern Body. Berkeley: University of California Press. 
Gelman, S. A., Collman, P., Maccoby, E. E. 1986. „Inferring properties from categories versus inferring categories from properties: The case of gender." Child Development, 57: 396-404.

Gerber, M. 1992. Vested Interests: Cross-dressing and Cultural Anxiety. New York a London: Routledge.

Gibbs, J. T. 1988a. „Health and mental health of young Black males.“ In J. T. Gibbs a kol. Young Black and Male in America: An Endangered Species. Dover, Mass.: Auburn House.

Gibbs, J. T. 1988b. „,The new morbidity: Homicide, suicide, accidents, and life-threatening behaviors." In J. T. Gibbs a kol. Young Black and Male in America: An Endangered Species. Dover, Mass.: Auburn House.

Gilbert, S. M. 1983. „Soldier's heart: Literary men, literary women, and the Great War.“ Signs, 8: 422-450.

Gitlin, M. J., Pasnou, R. O. 1989. „Psychiatric syndromes linked to reproductive function in women: A review of current knowledge." American Journal of Psychiatry, 146: 1413-1421.

Glassner, B. 1992. „Men and muscles.“ In M. S. Kimmel, M. A. Messner (eds.) Men's Lives. New York: Macmillan.

Goffman, E. 1963. Stigma. Englewood Cliffs, N. J.: Prentice-Hall.

Goodman, M. 1980. „Toward a biology of menopause.“ Signs, 5: 739-753.

Goodman, M. 1982. „A critique of menopause research.“ In A. M. Voda, M. Dinnerstein, S. R. O’Donnell (eds.) Changing Perspectives on Menopause. Austin: University of Texas Press.

Gove, W. R. 1984. „Gender differences in mental and physical illness: The efects of fixed roles and nurturant roles." Social Science and Medicine, 19: 77-91.

Greil, A. L., Leitko, T. A., Porter, K. L. 1988. „Infertility: His and hers.“ Gender \& Society, 2: 172-199.

Grieco, M., Whipp, R. 1986. „Women and the workplace: Gender and control in the labor process.“ In D. Knights, H. Willmott (eds.) Gender and the Labor Process. Hampshire, England: Gower.

Guinan, M. E. 1988. „PMS or perifollicular phase euphoria?“ Journal of the American Medical Women's Association, 43: 91-92 .

Hall, M. A. 1988. „The discourse of gender and sport: From femininity to feminism.“ Sociology of Sport Journal, 5: 330-340.

Hargreaves, J. A. (ed.) 1982. Sport, Culture and Ideology. London: Routledge and Kegan Paul.

Hargreaves, J. A. 1986. „Where's the virtue? Where's the grace? A discussion of the social production of gender relations in and through sport." Theory, Culture, and Society, 3: 109-121.

Harrison, J., Chin, J., Ficarrotto. T. 1992. „Warning: Masculinity may be dangerous to your health.“ In M. S. Kimmel, M. A. Messner Men's Lives. New York: Macmillan.

Hartmann, H. (ed.) 1987. Computer Chips and Paper Clips: Technology and Women's employment. Vol. 2. Washingon D. C.: National Academy Press.

Hartmann, H. I., Kraut, R. E., Tilly, L. A. (eds.) 1987. Computer Chips and Paper Clips: Technology and Women's employment. Vol. 1. Washingon D. C.: National Academy Press. 
Haskell, M. 1989. „Hers: He Drives me crazy.“ New York Times Magazine, 24. 9., 26, 28.

Heitlinger, A. 1987. Reproduction, Medicine, and the Socialist State. New York: St. Martin's Press.

Hoffmann, J. C. 1982. „Biorhythms in human reproduction: The not-so-steady states.“ Signs: 829-844.

hooks, b. 1981. Ain't I a Woman: Black Women and Feminism. Boston: South End Press.

Hubbard, R. 1990. The Politics of Women's Biology. New Brunswick, N. J.: Rutgers University Press.

Hubbard, R., Henifin, M. S., Fried, B. (eds.) 1979. Women Look at Biology Looking at Women. Boston: G. K. Hall.

Hudson, J. 1978. „Physical parameters used for female exclusion from law enforcements and athletics." In C. A. Oglesby (ed.) Women and Sport: From Myth to Reality. Philadelphia: Lea and Febiger.

Hyde, J. S. 1990. „Meta-analysis and the psychology of gender differences.“ Signs, 16: 55-73.

Jackson, J. J., Perry, Ch. 1989. „Physical health conditions of middle-aged and aged Blacks.“

In K. S. Markides (ed.) Aging and Health: Perspecives on Gender, Race, Ethnicity, and Class. Newbury Park, Calif.: Sage.

Jacobus, M., Keller, E. F., Shuttleworth, S. (eds.) 1990. Body/Politics: Women and the Discourses of Science. New York a London: Routledge.

Janofsky, M. 1992. „Yamaguchi has the delicate and golden touch.“ New York Times, 22. 2.

Jones. J. 1986. Labor of Love, Labor of Sorrow: Black Women, Work and the Family from Slavery to the Present. New York: Vintage.

Jordanova, L. 1989. Sexual Visions: Images of Gender in Science and Medicine between the Eighteenth and Twentieth Centuries. Madison: University of Wisconsin Press.

Kearns, B. J. R. 1982. „Perceptions of menopause by Papago Women.“ In A. M. Voda, M. Dinnerstein, S. R. O’Donnell (eds.) Changing Perspectives on Menopause. Austin: University of Texas Press.

Kemper, T. D. 1990. Social Structure and Testosterone: Explorations of the Socio-biosocial Chain. New Brunswick, N. J.: Rutgers University Press.

Kessler, S. J. 1990. „,The medical construction of gender: Case management of intersexed infants." Signs, 16: 3-26.

Kessler, S. J., McKenna W. 1985 [1978]. Gender: An Ethnometodological Approach. Chicago: University of Chicago Press.

Koeske, R. D. 1983. „Lifting the curse of menstruation: Toward a feminist perspective on the menstrual cycle." Women and Health, 8 (2-3): 1-15.

Kolata, G. 1992. „Track federation urges end to gene tests for femaleness.“ New York Times, 12. 2 .

Kramer, P. E., Lehman, S. 1990. „Mismeasuring women: A critique of research on computer ability and avoidance." Signs, 16: 158-172.

Laqueur, T., 1990a. Making Sex: Body and Gender from the Greeks to Freud. Cambridge, Mass.: Harvard University Press.

Laqueur, T. 1990b. „The facts of fatherhood.“ In M. Hirsch, E. Fox Keller (eds.) Conflicts in Feminism. New York a London: Routledge. 
Laws, S. 1983. „The sexual politics of premenstrual tension.“ Women's Studies International Forum, 6: 19-31.

LeMoyne, J. 1990. „Ban on driving by women: reaffirmed by Saudis.“ New York Times, 15. 11.

Lennane, K. J., Lennane, R. J. 1973. „Alleged psychogenic disorders in women - a possible manifestation of sexual prejudice." New England Journal of Medicine, 288: 288-292.

Levesque-Lopman, L. 1988. Claiming Reality: Phenomenology and Women's Experience. Totowa, N. J.: Rowman \& Littlefield.

Levy, J. A. 1988. „Intersections of gender and aging.“ Sociological Quarterly, 29: 479-486.

Longino, H. E., Doell, R. 1983. „Body, bias, and behaviour: A comparative analysis of reasoning in two areas of biological science." Signs, 9: 206-227.

Lorber, J. 1967. „Deviance as performance: The case of illness.“ Social Problems, 14: 302310.

Lorber, J. 1987. „In vitro fertilisation and gender politics.“ Women \& Health, 13: 117-133.

Lorber, J. 1989. „Choice, gift, or patriarchal bargain? Women's consent to in vitro fertilisation in male fertility." Hypatia, 4: 23-36.

Lorber, J., Bandlamudi, L. 1993. „Dynamics of marital bargaining in male infertility.“ Gender \& Society, 7: 32-49.

MacKinnon, C. A. 1987. Feminism Unmodified. Cambridge, Mass.: Harvard University Press.

Majors, R. 1990. „Cool pose: Black masculinity in sports.“ In M. A. Messner, D. F. Sabo (eds.) Sport, Men, and the Gender Order: Critical Feminist Perspectives. Champaign, Ill.: Human Kinetics.

Mangan, J. A., Park, J. 1987. From Fair Sex to Feminism: Sport and the Socialisation of Women in the Industrial and Post-industrial Eras. London: Frank Cass.

Martin, E. 1987. The Woman in the Body: A Cultural Analysis of Reproduction. Boston: Beacon Press.

Matthaei J. A. 1982. An Economic History of Women's Work in America. New York: Schocken.

McClintock, M. 1979. „Considering, A biosocial perspective on parenting“ “ Signs, 4: 703-710.

McCrea, F. B. 1986. „The politics of menopause: The ,discovery“ of a deficiency disease.“ In P. Conrad, R. Kern The Sociology of Health and Illness. New York: St. Martin's Press.

Messner, M. 1987. „The meaning of success: The athletics experience and the development of male identity." In H. Brod (ed.) The Making of Masculinities. Boston: Alien \& Unwin.

Messner, M. 1989. „Masculinities and athletics careers.“ Gender \& Society, 1: 71-88.

Messner, M. A. 1988. „Sports and male domination: The female athlete as contested ideological terrain." Sociology of Sport Journal, 5: 197-211.

Messner, M. 1992. Power at Play: Sports and the Problem of Masculinity. Boston: Beacon Press.

Messner, M. A., Duncan, M. C., Jensen, K. 1993. „Separating the men from girls: The gendered landscape of televised sports." Gender \& Society, 7: 121-137.

Messner, M. A., Sabo, D. F. (eds.) 1990. Sport, Men, and the Gender Order: Critical Feminist Perspectives. Champaign, Ill.: Human Kinetics.

Miall, Ch. E. 1986. „The stigma of involuntary childlesness.“ Social Problems, 33: 268-282. 
Moloch, H. 1988. „The restroom and equal oportunity.“ Sociological Forum, 3: 128-132.

Money, J., Ehrhardt, A. A. 1972. Man \& Woman, Boy \& Girl. Baltimore, Md.: Johns Hopkins University Press.

Moran, M. 1992. „Title IX: A 20-year search for equity.“ New York Times, Sports Section, 21, 22, 23. 6.

Muller, Ch. 1990. Health Care and Gender. New York: Russell Sage Foundation.

Naftolin, F., Butz, E. (eds.) 1981. „Sexual dimorphism.“ Science, 211: 1263-1324.

Nathanson, C. A. 1975. „Illness and the feminine role: A theoretical review.“ Social Science and Medicine, 9: 57-62.

New York Times. 1989. „Gymnastic girls, not women.“ 1. 8.

New York Times. 1990. „Woman is acquitted in trial for using the men's room.“ 3. 11.

Nsiah-Jefferson, L., Hall, E. J. 1989. „Reproductive technology: Perspectives and implications for low-income women and women of color." In K. S. Ratcliff a kol. (eds.) Healing Technology: Feminist Perspectives. Ann Arbor: University of Michigan Press.

O'Brien, M. 1981. The Politics of Reproduction. New York: Routledge.

Olson, W. 1990. „Beyond Title IX: Toward an agenda for women and sports in the 1990's.“ Yale Journal of Law and Ferminism, 3: 105-151.

Ory, M., Warner, H. R. 1990. Gender, Health and Longevity. New York: Springer.

Parlee, M. B. 1973. „The premenstrual syndrome.“ Psychological Bulletin, 80: 454-465.

Parlee, M. B. 1982a. „The psychology of menstrual cycle: Biological and psychological perspectives." In R. C. Friedman (ed.) Behavior and the menstrual cycle. New York: Marcel Dekker.

Parlee, M. B. 1982b. „Changes in moods and activation levels during the menstrual cycle in experimentally naïve subjects.“ Psychology of Women Quarterly, 7: 119-131.

Perlmutter, E., Bart, P. 1982. „Changing views of , the change': A critical review and suggestions for an attributional approach.“ In A. M. Voda, M. Dinnerstein, S. R. O’Donnell (eds.) Changing Perspectives on Menopause. Austin: University of Texas Press.

Perry, R., Greber, L. 1990. „Women and computers: An introduction.“ Signs, 16: 74-101.

Petchesky, R. P. 1979. ,Workers, reproductive hazards, and the politics of protection: An introduction." Feminist Studies, 5: 233-245.

Pomeroy, S. B. (ed.) 1991. Women's History and Ancient History. Chapel Hill: University of North Carolina Press.

Powers, M. N. 1980. „Menstruation and reproduction: An Oglala case.“ Signs, 6 (1, 2): 24-65.

Prior, J. C. a kol. 1990. „Spinal bone loss and ovulatory disturbances.“ New England Journal of Medicine, 323: 1221-1227.

Rich, A. 1977. Of Woman Born: Motherhood as Experience and as Institution. New York: Norton.

Rittenhouse, C., A. 1991. „The emergence of premenstrual syndrome as a social problem.“ Social Problems, 38: 412-425.

Rossi, A. S. 1980. „Life span theories and women’s lives.“ Signs, 6 (1, 2): 4-32.

Rossi, A. S., Rossi, P. E. 1977. „Body time and social time: Mood patterns by menstrual phase and day of the week." Social Science Research, 6: 273-308. 
Rothman, B. K. 1989. Recreating Motherhood: Ideology and Technology in a Patriarchal Society. New York: Norton.

Rothschild, J. 1983. „Technology, housework, and women's liberation: A theoretical analysis. In J. Rothschild (ed.) Machina ex dea: Feminist Perspectives on Technology. New York: Pergamon.

Sandelowski, M. 1990. „Faul lines: Infertility and imperiled sisterhood.“ Feminist Studies, 16: 33-51.

Sanders, P. 1991. „Gendering the ungendered body: Hermaphrodites in medieval Islamic law.“ In N. R. Keddie, B. Baron (eds.) Women in Middle Eastern History: Shifting Boundaries in Sex and Gender. New Haven: Yale University Press.

Sayers, J. 1982. Biological Politics: Feminist and Anti-feminist Perspectives. London and New York: Tavistock.

Scharff, V. 1991. Taking the Wheel: Women and the Coming of the Motor Age. New York: Free Press.

Slatton, B., Birrell, S. (eds.) 1984. „The politics of women’s sport.“ Arena Review, 8 (July).

Stellman, J. M., Henifin, M. S. 1982. „No fertile women need apply: Employment discrimination and reproductive hazards in the workplace." In R. Hubbard, M. S. Henifin, B. Fried (eds.) Biological Woman - the Convenient Myth. Cambridge, Mass.: Schenckman.

Theberge, N. 1987. „Sport and women's empowerment.“ Women's Studies International Forum, 10: 387-393.

Theberge, N., Cronk, A. 1986. „Work routines in newspaper sports departments and the coverage of women's sports.“ Sociology of Sport Journal, 3: 195-203.

Treadwell, P. 1987. „Biologic influences on masculinity.“ In H. Brod (ed.) The Making of Masculinities. Boston: Alien \& Unwin.

Turkle, S., Papert, S. 1990. „Epistemological pluralism: Styles and voices within the computer culture." Signs, 16: 128-157.

Ullrich, H. E. 1982. „Menstrual taboos among Havik Brahmin women: A study of ritual change. "Sex Roles, 26: 19-20.

Vecsey, G. 1990. „Cathy Rigby, unlike peter, did grow up.“New York Times, 19. 12.

Verbrugge, L. M. 1985. „Gender and health: An update on hypotheses and evidence.“ Journal of Health and Social Behavior, 26: 156-182.

Verbrugge, L. M. 1986. „Role burdens and physical women and men.“ Women \& Health, 11: 47-77.

Verbrugge, L. M. 1989a. „The twain meet: Empirical explanations of sex differences in health and mortality.“ Journal of Health and Social Behavior, 30: 282-304.

Verbrugge, L. M. 1989b. „Gender, aging, and health.“ In K. S. Markides (ed.) Aging and Health: Perspecives on Gender, Race, Ethnicity, and Class. Newbury Park, Calif.: Sage.

Vertinsky, P. 1990. The eternally wounded woman: Women, Doctors and Excercise in the Late Nineteenth Century. Manchester, England: Manchester University Press.

Vogel, L. 1990. „Debating difference: Feminism, pregnancy, and the workplace.“ Feminist Studies, 16: 9-32.

Watson, T. 1987. „Women athletes and athletics women: The dilemmas and contradictions of managing incongruent identities." Sociological Inquiry, 57: 431-446. 
Weiss, M. (v tisku) „Fence sisters: Parents reactions to sexual ambiguities in their newborn children." Semiotica.

Wheelwright, J. 1989. Amazons and Military Maids: Women who Cross-dressed in Pursuit of Life, Liberty, and Happiness. London: Pandora Press.

White, D. G. 1985. Ar'n't I a Woman? Female Slaves in the Plantation South. New York: Norton.

Willis, P. 1982. „Women in sport in ideology.“ In J. A. Hargreaves (ed.) Sport, Culture, and Ideology. London: Routledge and Kegan Paul.

Wilson, E. O. 1975. Sociobiology: The New Synthesis. Cambridge, Mass.: Harvard University Press.

Wilson, E. O. 1978. On Human Nature. Cambridge, Mass.: Harvard University Press.

Wright, A. L. 1982. „Variation in Navajo Menopause: Toward an explanation.“ In A. M. Voda, M. Dinnerstein, S. R. O’Donnell (eds.) Changing Perspectives on Menopause. Austin: University of Texas Press.

Wright, B. D. a kol. (eds.) 1987. Women, Work, and Technology: Transformations. Ann Arbor: University of Michigan Press.

Wright, M. J. 1979. „Reproductive hazards and ,protective“ discrimination.“ Feminist Studies, 5: 302-309.

Yankauskas, E. 1990. „Primary female syndromes: An update.“ New York State Journal of Medicine, 90: 295-302.

Yoder, J. D. 1989. „Women at West Point: Lessons for token women in male-dominated occupations.“ In J. Freeman (ed.) Women: A Feminist Perspective. Mountain View, Calif.: Mayfield.

Young, I. M. 1990. Throwing Like a Girl and Other Essays in Feminist Philosophy and Social Theory. Bloomington: Indiana University Press.

Zimmermann, J. 1983. The Technological Woman: Interfacing with Tomorrow. New York: Praeger.

Zita, J. 1988. „The premenstrual syndrome: ,Dis-easing” the female cycle.“ Hypatia, 3: 77-99.

Zola, I. K. (ed.) 1982. Missing Pieces: A Chronicle of Living with a Disability. Philadelphia: Temple University Press.

\section{Autorka}

Judith Lorber je emeritní profesorkou na Brooklyn College and Graduate School na City University v New Yorku. V letech 1985-86 byla viceprezidentkou Východní sociologické asociace a v letech 1992-93 předsedkyní genderové sekce Americké sociologické asociace (ASA). V roce 1997 obdržela Jessie Bernard Career Award udělovanou Americkou sociologickou asociací. V roce 1986 spoluzakládala a později spoluvydávala renomovaný časopis Gender \& Society. Je mimo jiné autorkou knih Gender Inequality (1998), Paradoxes of Gender (1994), Women Physicians: Careers, Status, and Power (1984).

Překlad převzat z: Lorber, J. 1994. „Believing is Seeing. Biology as Ideology.“ In Paradoxes of Gender, Yale University, s. 37-53. 